\title{
10
}

\section{DIMENSIONS OF THE PETROLEUMSCAPE IN THE PORT AND THE CITY OF HAMBURG}

\author{
Christoph Strupp
}

At its annual press conference in 2017, the marketing company of the port of Hamburg presented slides with data on the development of the port during the previous year. Seventeen of the thirty-five slides focused on container handling. Bulk cargo, which includes petroleum, consisted of three slides and received the same limited space as cruise ship tourism. ${ }^{1}$ Although Hamburg, as Germany's largest seaport, prides itself on its status as a "universal port" for all kinds of goods and services, the implicit message sent to customers and the public was that the port of Hamburg is primarily a container port. While containers indeed make up two-thirds of total turnover and generate the most value for the port, liquid cargo still accounts for 10 percent of total turnover. Of the 4,226 ha of land in the port area, about 12 percent is occupied by storage and production facilities pertaining to the oil industry, which remains a profitable pillar of the local economy. Headquarters of several oil companies are located in Hamburg, as are some oil lobby associations. Although local actors in the port economy and economic politics may have downplayed the significance of oil and oil handling in recent years, Germany's second-largest city remains an important node in the global petroleumscape.

The global petroleumscape, according to Carola Hein, consists of three interconnected layers (see also Hein's Introduction in this volume). The model emphasizes spatial dimensions of oil in the nineteenth and twentieth centuries and sheds light on the multitude of private and public actors involved in creating the petroleumscape. ${ }^{2}$ This chapter explores the oil history in the port of Hamburg and focuses on the city's petroleumscape since the late nineteenth century, with an emphasis on the 1950s to 1980s. While Hamburg, like many other ports and port cities, has been serving as an important junction in the physical flow of oil around the globe, ${ }^{3}$ and was publicly characterized as Germany's "oil city" in the interwar years and in the 1950s, the port and the city were not as intensively shaped by oil and the oil industry as, for example, Rotterdam. Therefore, the focus of "Hafen Hamburg Marketing e.V." on general cargo in its press conference in 2017 was no coincidence. Since emerging as one of Europe's leading overseas ports in the late nineteenth century, in Hamburg, port and trade have always been more closely linked than port and industry. ${ }^{4}$ Emblematic of Hamburg as a city of trade was the "Speicherstadt" from the 1880s with its 
brick warehouses for coffee, cacao, and general cargo, and the nearby "Kontorhausviertel," with its office buildings, from the 1920 s to the 1930 s. ${ }^{5}$ This identity as a trading city was reinforced in the late 1960s, when the first container ships arrived in the port. Today, the Speicherstadt and the Kontorhausviertel are UNESCO World Heritage sites and tourist attractions, and three of Hamburg's four container terminals provide impressive views from the northern riverbank of the Elbe for locals and tourists alike. In contrast, most of the port's industrial sites are located out of sight in the southern part of the port (Figure 10.1). ${ }^{6}$

\section{Expansion of the Industrial and Administrative Dimensions of the Petroleumscape from the Kaiserreich to the Third Reich}

The spatial layer of the petroleumscape developed in Hamburg in the second half of the nineteenth century. The first barrels of oil arrived in the port from the US in 1861. In 1876, city officials' security concerns about the new flammable commodity resulted in the first expansion of the port-from the northern to the southern riverbank of the Norderelbe at Kleiner Grasbrook. Beginning in the late 1870s, a number of petroleum refineries were built in the port of Hamburg and the neighboring Prussian district of Harburg and Wilhelmsburg in the south. They included Ölwerke Ernst Schliemann (1879), Mineralölwerke Albrecht \& Co. (1884), Ölwerke Stern-Sonneborn (1889), Johann Haltermann (1898), Ölwerke Julius Schindler (1908), and the Deutsche Vacuum Oil (1911), thus adding a new segment to the port-bound industry close to the waterfront. They benefited from the port's excellent hinterland connection to Berlin and the Saxon industrial area and-after 1888 - from the port's newly granted free port status. ${ }^{7}$

In 1910, a new tank ship port was built at the western end of the port at Waltershof and, in the 1920s, additional storage and processing facilities for oil were installed at Waltershof, Kleiner Grasbrook, and in Harburg and Wilhelmsburg along the Süderelbe. These facilities consolidated Hamburg's position as oil center of the German Reich, even if the share of crude oil and oil products in total port turnover was limited (see Table 10.1). In the interwar years, up to 90 percent of German crude oil imports and most of the imported finished products such as gasoline passed through Hamburg. Contemporary aerial images show rows of storage tanks and production plants at several locations in the port area.

Hamburg was not only a central node in the industrial and infrastructure layers of the petroleumscape, but also an administrative hub. The company headquarters of ten of the largest German oil-processing companies-most of them in international hands-were located in the greater Hamburg area, accompanied by a large number of smaller companies based in various parts of the city. A commercial directory of Hamburg from 1922 lists almost 200 oil-related producers and distributors. Many of them had offices at prestigious addresses such as Rödingsmarkt, Hohe Bleichen, Mönckebergstraße, Glockengießerwall, and Alsterdamm. ${ }^{8}$ Driven by the needs of local businesses, a separation of urban functions had begun in the nineteenth century and continued in the interwar years. Banks, trading houses, shipping companies, and industrial administrations clustered in the inner city. ${ }^{9}$ In 1938, the Deutsch-Amerikanische Petroleum-Gesellschaft (DAPG) moved-in the words of the "Hamburger Nachrichten"-into a "new giant building at the Binnenalster" 10 that could easily match the other company headquarters there. The "Hamburger Fremdenblatt" emphasized that the new headquarters should "significantly influence the cityscape 


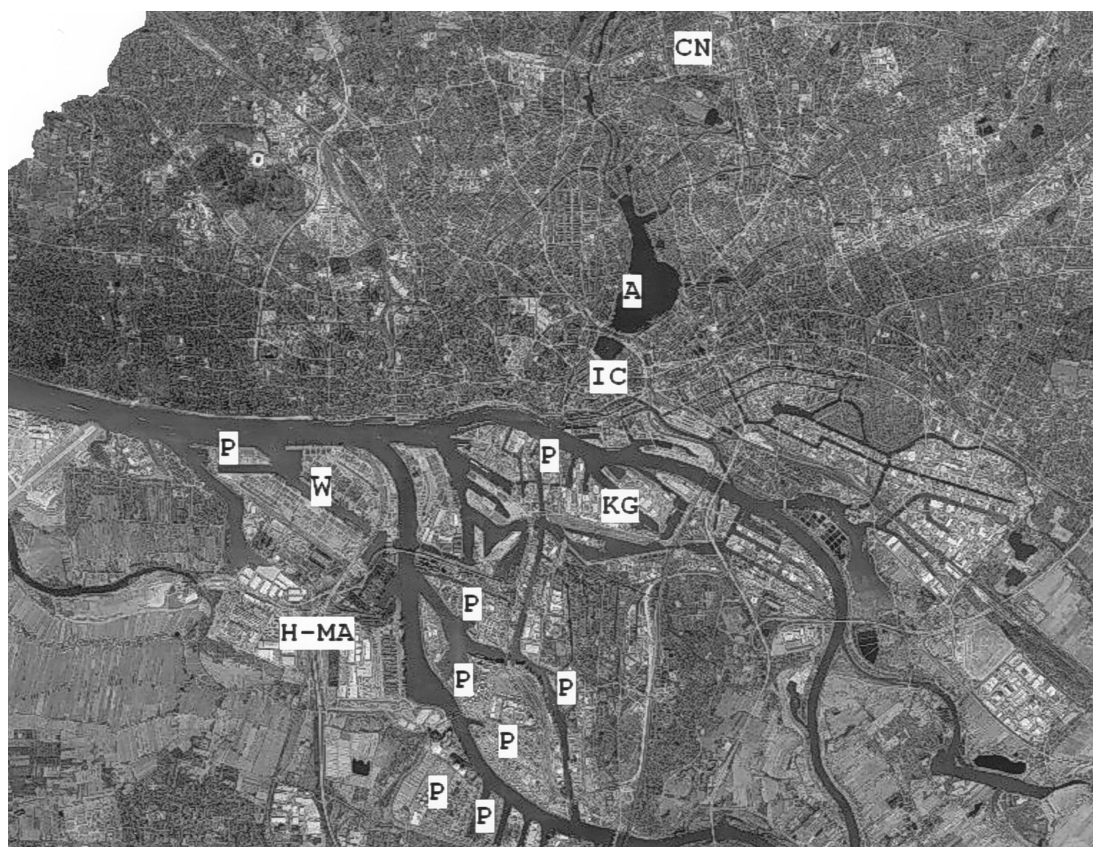

FIGURE 10.1 The city of Hamburg and the port area. P: Petroleum industrial sites; A: Alster; IC: Inner City; CN: City Nord; W: Waltershof; KG: Kleiner Grasbrook; H-MA: Hamburg-Moorburg and Altenwerder. Source: Creation by the author, based on an orthophoto of Stadt- und Landschaftsplanung Online (Planportal): https://www. hamburg.de/planportal/, Freie und Hansestadt Hamburg, Landesbetrieb Geoinformation und Vermessung, Data licence Germany - attribution - Version 2.0 (https://www.govdata.de/dl-de/by-2-0). Used by permission.

TABLE 10.1 Petroleum and Total Cargo Turnover in the Port of Hamburg, 1861-1938

\begin{tabular}{lll}
\hline Year & $\begin{array}{l}\text { Petroleum and Mineral Oil Import at the } \\
\text { Port of Hamburg, in Tons }\end{array}$ & $\begin{array}{l}\text { Total Cargo Turnover at the Port of Hamburg, } \\
\text { in Tons }\end{array}$ \\
\hline 1861 & 160 & 872,300 \\
1871 & 40,000 & $2,663,000$ \\
1885 & 144,000 & $5,075,000$ \\
1900 & 375,000 & $14,432,000$ \\
1925 & 810,000 & $19,868,000$ \\
1938 & $3,700,000$ & $25,760,000$ \\
\hline
\end{tabular}

Sources: Dieter Maass, Der Ausbau des Hamburger Hafens 1840 bis 1910: Entscheidung und Verwirklichung (Hamburg: Hansa, 1990), 78, 79; Andreas Kunz and Lars U. Scholl, eds. Die deutsche Seeschifffahrt 1821-1989: Ein Datenhandbuch (Bremen: H. M. Hauschild, 2011), 529-30; Tabellarische Übersichten des hamburgischen Handels (Hamburg: Herold, 1886, 1901); Klaus Weinhauer, "Handelskrise und Rüstungsboom: Die Wirtschaft," in Hamburg im "Dritten Reich,” ed. Forschungsstelle für Zeitgeschichte in Hamburg (Göttingen: Wallstein, 2005), 216. 
according to modern architectural style." ${ }^{\prime 1}$ Illustrated press reports such as these formed part of the representational layer of the petroleumscape, as did popular corporate media such as city maps with lists of sights to see and local gas stations.

In the Third Reich, in 1937, the Nazi regime merged the city of Hamburg with the neighboring Prussian cities of Altona, Harburg, Wilhelmsburg, and Wandsbek, which expanded Hamburg's territory from 415 to $745 \mathrm{~km}^{2}$. The merger brought the port and industrial sites of Harburg and Wilhelmsburg, with its oil storage and refinery installations, under Hamburg's control and therefore further strengthened the industrial petroleumscape in the port (Figure 10.2). It also opened up new opportunities for a territorial adjustment of the port area, which would become relevant after 1945. While the official economic policy of the Nazi regime was guided by the ideal of energy autarky, motorization and rearmament led to a rise in demand for crude oil and petroleum-based products, which domestic sources alone could not meet. Oil handling in the port of Hamburg increased and the port-based local industry maintained and even expanded production levels in the late 1930s and early 1940s before targeted Allied air raids took place in June, August, and December of 1944, inflicting major damage to the port and adjacent industrial areas. ${ }^{12}$
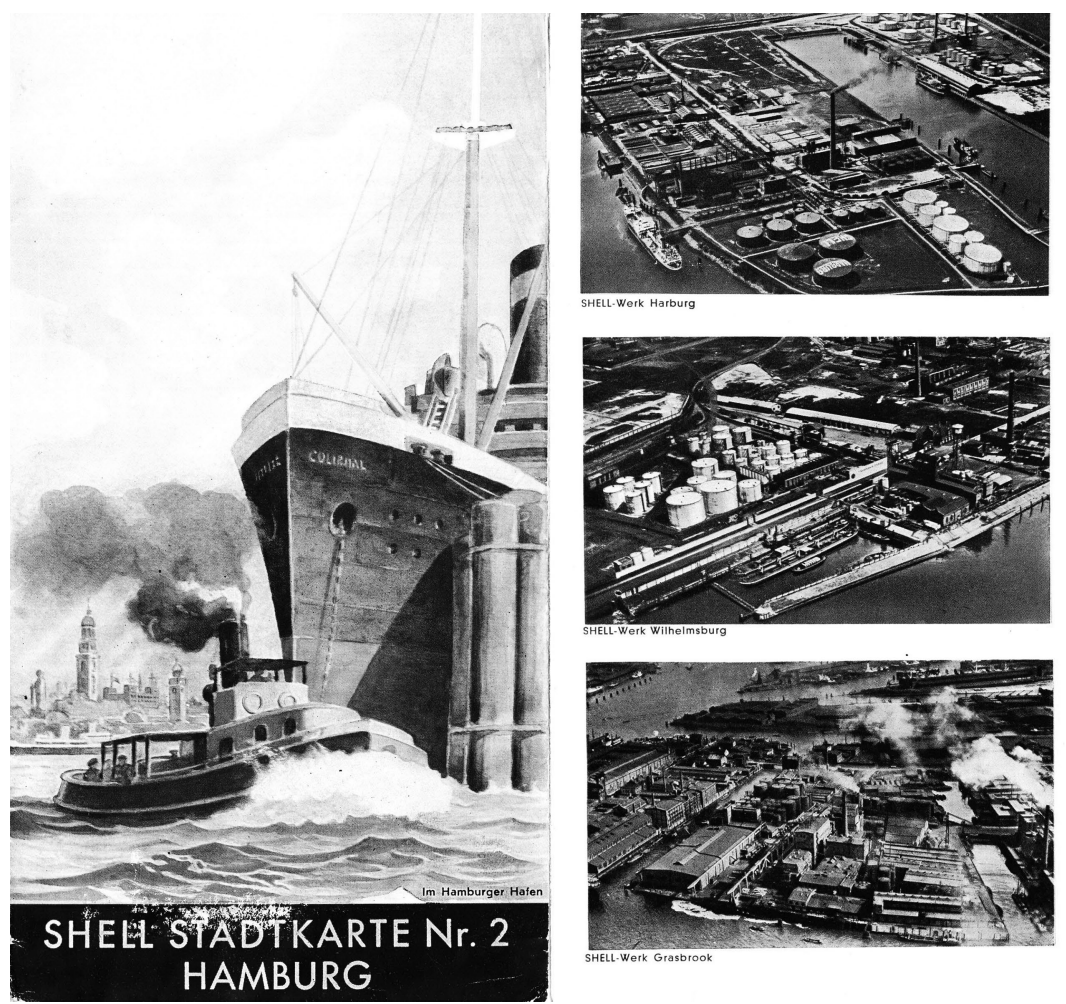

FIGURE 10.2 Shell City Map of Hamburg with aerial photos of the Shell industrial facilities in Hamburg, Wilhelmsburg, and Harburg, mid-1930s. Source: Collection C. Strupp. 


\section{Industrial, Infrastructure, and Administrative Layers of the Petroleumscape in Hamburg in the Economic "Boom" of the 1950s}

After World War II, the goal of making energy as cheap as possible soon dominated economic policies. The third quarter of the twentieth century saw a phenomenal rise in the use of oil, which replaced coal as the main energy carrier. In 1950, oil comprised 14 percent of energy demand in Europe; in 1970, its share was 60 percent. ${ }^{13}$ Petroleum products were used in transportation, for heating and power generation, and more and more consumer products were based on oil derivatives. In the German Federal Republic, crude oil consumption rose from 4.5 million tons in 1955 to 83.6 million tons in 1965 and 110 million tons in 1973. The oil industry linked its product to economic progress and prosperity: "A revival and a gradual return to normal living conditions was unthinkable without a perfusion of the economy with oil," stated a 1951 brochure of Esso AG, the successor of the DAPG. ${ }^{14}$

In Hamburg, West Germany's hunger for oil-most of which had to be imported from oil-producing regions in the Middle East and North Africa-strengthened the port-based spatial layer of the petroleumscape, in particular industry, infrastructure, and administration. In the port, for two decades ever-larger tank ships and an expanding oil industry rather than the needs of general cargo would shape its spatial restructuring and expansion. In 1947, a new general development plan for the port included additional space for industrial plants by activating little used areas of port land along the Süderelbe. ${ }^{15}$ However, in the immediate postwar years, priority was placed on the rebuilding of the destroyed facilities in the port and the reestablishment of the existing storage and refinery capacities at Waltershof, in Harburg, and Wilhelmsburg. In 1947, the Harburg asphalt plant of the DAPG/Esso AG restarted production. The Oelwerke Julius Schindler rebuilt their original refinery for oil products, and in 1949 expanded their facilities with a pipe distillation plant to process crude oil. Additional facilities for lube oil and sodium were added in the 1950s. In 1951, the Oelwerke became a subsidiary of the Anglo-Iranian Oil Company, the later BP. In November 1949, the rebuilt Harburg plant of Deutsche Shell AG was inaugurated with a festive event. ${ }^{16}$ In 1959, Shell opened a refinery with 520 storage tanks at Hohe Schaar in Wilhelmsburg. All major oil corporations were represented in Hamburg and all expanded their plants in the 1950s, although primarily on land that had already been part of the port - the area of Neuhof, Kattwyk, and Hohe Schaar in the west of Wilhelmsburg and the Harburg port area further to the south. Ten companies maintained storage tanks in the port, mostly at the petroleum port at Waltershof.

For ports all over the world, the rising influx of crude oil initially meant a significant increase in total turnover. In Hamburg, the total turnover increased from 1.8 million tons in 1945 to 10.9 million tons in 1950, 24.0 million tons in 1955, and 30.8 million tons in 1960. Crude oil turnover rose from 2.1 million tons in 1950 to 6.3 million tons in 1955 and 10.1 million tons in 1960, thus now accounting for about one-third of total turnover (see Table 10.2). Another statistic underlines the importance of oil for the port: in the late $1950 \mathrm{~s}$, the quota of general cargo turnover had reached only 89 percent of the 1936 level, while bulk goods stood at 158 percent and oil at 225 percent of what it had been in $1936 .^{17}$

The industrial and infrastructure layers of the petroleumscape expanded. Oil increased local traffic at the port and strengthened the industrial sector in Hamburg; it provided jobs in the shipbuilding industry and stimulated economic recovery in general. This economic 
importance was mirrored in the representational petroleumscape: in the 1950s, Hamburg was called the German "oil city" and the "oil center of the Federal Republic."18 Local media reported regularly on the presence of the first mayor or the minister for economic affairs at the opening ceremonies for rebuilt or newly constructed production plants.

In 1954, at the fourth Hamburg "Overseas Day"- a lobbying event for business and politics, which takes place yearly around the "harbor birthday" of May 7-on the grounds of the Esso refinery in Hamburg-Harburg, the guest of honor, German Chancellor Konrad Adenauer, gave a friendly welcome speech (Figure 10.3). Later in the year, German President Theodor Heuss, during his state visit to Hamburg, also visited Esso. A press report characterized the pipes of the Esso refinery as "towers of the twentieth century," made of steel and aluminum instead of stone. ${ }^{19}$

In the mid-1950s, the industry employed approximately 5,500 employees each in the industrial plants and in administrative functions. ${ }^{20}$ While the storage tanks and refineries were located in the port area, the administrative layer of the petroleumscape was concentrated in the inner city. As in the interwar years, the Hamburg-based company headquarters of Deutsche Shell AG, Deutsche BP AG, Esso AG and others were housed at prominent addresses such as Neuer Jungfernstieg, Alsterufer, Steinstraße, Hohe Bleichen, or Glockengießerwall. Trade associations such as the Mineralölwirtschaftsverband e.V. founded in Hamburg in September 1946 or the Uniti-Vereinigung deutscher Kraftstoffgroßhändler e.V. founded in July 1947 and specialist publishers were also located in Hamburg. ${ }^{21}$

TABLE 10.2 Crude Oil, Mineral Oil Products and Total Cargo Turnover in the Port of Hamburg, 1945-2005

\begin{tabular}{llll}
\hline Year & $\begin{array}{l}\text { Crude Oil Turnover, in } \\
\text { Millions of Tons (Import } \\
\text { Only) }\end{array}$ & $\begin{array}{l}\text { Mineral Oil Products Turnover, } \\
\text { in Millions of Tons (Import and } \\
\text { Export Over Sea) }\end{array}$ & $\begin{array}{l}\text { Total Cargo Turnover, in } \\
\text { Millions of Tons }\end{array}$ \\
\hline 1945 & $0.9[1946]$ & & 1.8 \\
1950 & 2.1 & & 11.0 \\
1955 & 6.3 & & 24.0 \\
1960 & 10.2 & & 30.8 \\
1965 & 13.1 & 7.6 & 35.1 \\
1970 & 12.12 & 7.05 & 47.1 \\
1975 & 10.85 & 8.19 & 48.6 \\
1980 & 9.85 & 9.42 & 63.1 \\
1985 & 3.68 & 9.6 & 59.52 \\
1990 & 4.16 & 7.27 & 61.36 \\
1995 & 4.82 & 5.96 & 72.12 \\
2000 & 4.28 & 6.75 & 85.09 \\
2005 & 4.42 & & 125.74 \\
\hline
\end{tabular}

Sources: Behörde für Wirtschaft und Verkehr, Hafen Hamburg 1945-1965: Zwanzig Jahre Aufbau und Entwicklung (Hamburg: Behörde für Wirtschaft und Verkehr, 1965), 43-46; Klaus-Jürgen Juhnke, "Die Bedeutung der Mineralölindustrie des Hamburger Hafens für Kosten und Erträge des Hamburger Staates" (Thesis, University of Hamburg, 1962), 56; Werner Klugmann, Tatsachen, Daten und Zahlen über den Hamburger Hafen (Hamburg: Okis, 1966), 131; Statistikamt Nord, Schiffahrt und Außenhandel Hamburgs 1970 bis 2009 (Hamburg: Statistisches Amt für Hamburg und Schleswig-Holstein, 2010), 6. 


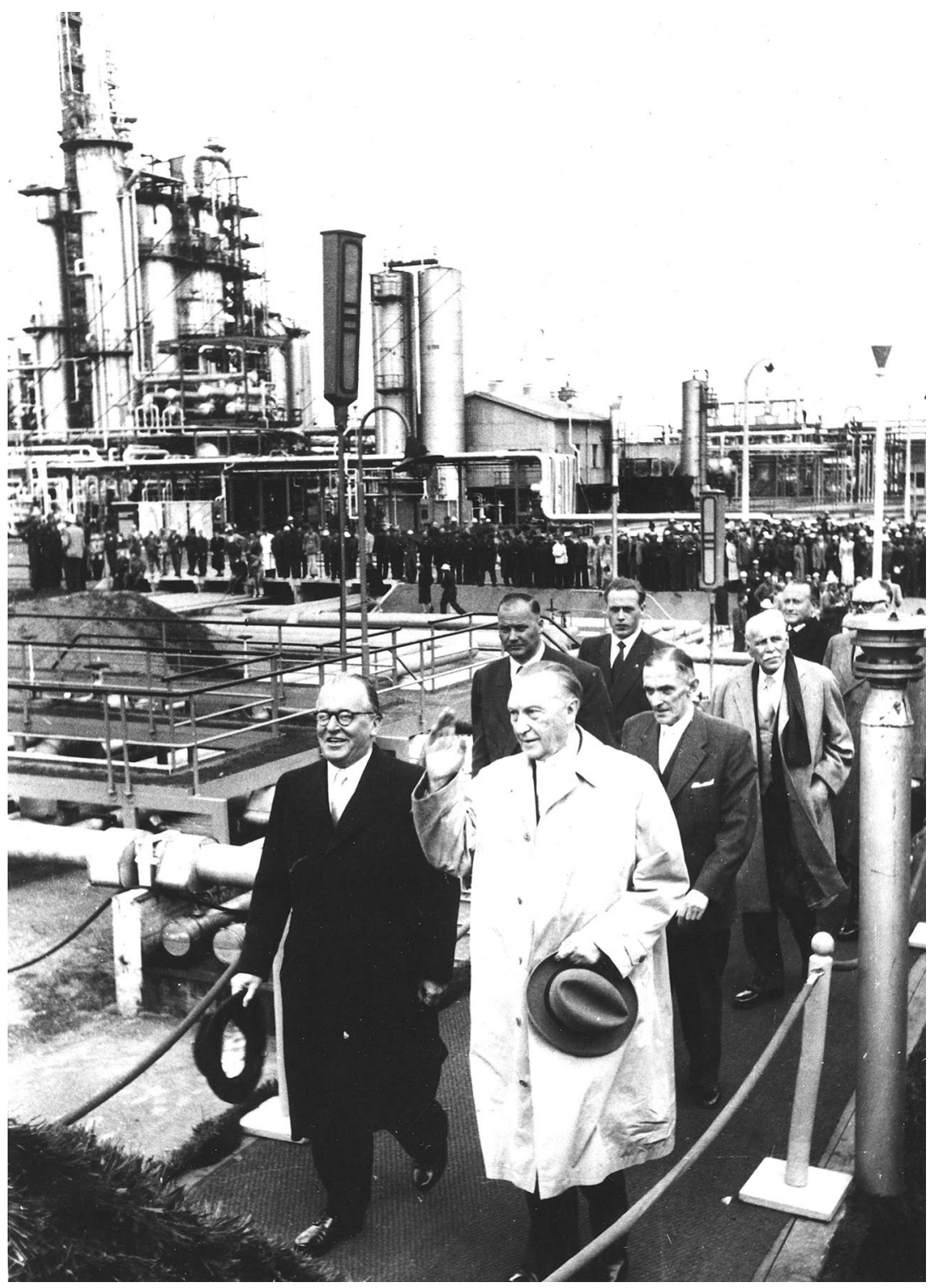

FIGURE 10.3 German Chancellor Konrad Adenauer visits the Esso Refinery in HamburgHarburg, May 1954. Source: State Archive Hamburg. Used by permission.

The import of crude oil replaced some of the cargo volume lost in the East because of the division of Europe, and on-site processing of oil brought added value for the city. From a spatial perspective, however, it provided Hamburg - a city-state with fixed political boundaries and an upstream port about $120 \mathrm{~km}$ away from the Elbe estuary-with two major challenges: providing land for the industry and keeping up with the rapidly growing size of the ships. For both problems, port planners developed solutions that tried to meet the spatial needs and the interests of the oil industry without neglecting the interests of other established players in the port, particularly general cargo handling. 
Since the early 1950s, the Ministry for Economic Affairs was in talks with representatives of the oil companies to accommodate their expansion plans. The city purchased agricultural land in Moorburg in the southwest, adjacent to the existing industrial sites, ever-rising prices because the farmers were aware of the value of their property, and then leased it to the oil industry for new production facilities. ${ }^{22}$ Michael Miller has described how multinational companies Shell, Esso, and the others exercised "relentless pressure and blackmail" to dictate their conditions to port cities all over Europe. ${ }^{23}$ In Hamburg, too, hardly any of the correspondence of the German CEOs with the ministry or the first mayor concerning the size of the locations, division of costs, or timetables lacked a reference to the allegedly favorable settlement conditions in the Rhineland. ${ }^{24}$ The city was confronted with effects of the global character of the petroleumscape: local authorities were dealing with the German branches of multinational companies with production facilities in various locations for whom it did not necessarily matter to keep administration and production units together. The global petroleumscape threatened to overwrite local ties and Hamburg's politicians could not count on sentimental feelings toward their "oil city."

The director of Hamburger Hafen- und Lagerhaus AG (HHLA), a publicly held company in charge of much of the port operations, and then-Minister for Port Affairs Ernst Plate, a key player in Hamburg's port activities in the 1950s and 1960s, pointed out in parliament in June 1956:

During the past weeks and months you have all read the frequent good press reports about the new anchoring of the mineral oil industry in the West German region, in Cologne. This development, I want to say openly as a Hamburg citizen, has not been very pleasing for us [...]. In this situation, I believe I can take the view that we are all the more interested in making available to the local oil industry all the facilities it needs to further expand its capacity. ${ }^{25}$

For this position, Plate could count on the support of all political parties and the local media.

Since the available land for industrial development in the port was gradually depleted at the end of the 1950s, the Port Development Act of 1961 designated 2,500 ha of land in Hamburg-Moorburg and neighboring Altenwerder, west of the Süderelbe, as future port area and subjected the inhabitants to expropriation and resettlement. ${ }^{26}$

The growing size of ships, which owed much to oil, posed another challenge for many ports after World War II. ${ }^{27}$ In Hamburg in 1950, only two out of ninety-two tankers had a draft of more than $9.8 \mathrm{~m}$, while in 1959, 108 of the 346 arriving tank ships needed this water depth. ${ }^{28}$ In 1953, at the highly publicized Hamburg launch of the tanker Tina Onassis, the press mused whether an economic limit had been reached with its 35,000 tons. ${ }^{29}$ In May 1962, the Howaldtswerke in Hamburg celebrated with prominent guests and thousands of spectators the launch of the 88,000-ton tanker Esso Spain, the largest cargo ship built to date in Europe. Within months, the Esso Deutschland and the Esso Bayern, both capable of carrying 91,000 tons of oil, broke this record (Figure 10.4). ${ }^{30}$

In the second half of the 1960s, ship sizes had increased to 276,000 tons, and in 1972 the first tanker with a capacity of 447,000 tons was under construction. In light of Hamburg's upstream location, the scenario of large tankers being unable to reach the port fed the fear that the port would not be able to keep up with competitors Bremen, Rotterdam, and Antwerp. This fear had been a driving force behind Hamburg's economic policy decisions since $1945 .{ }^{31}$ 
After the initial focus on rebuilding and expanding existing structures, the spatial demands of oil led to broader redesign of parts of the port by local authorities. In August 1956, the city's Ministry for Economic Affairs issued a memorandum, "On the Question of Hamburg's Tank Ship Ports," which predicted a further increase in oil turnover, a significant increase in ship arrivals, and a need for new processing plants. ${ }^{32}$ The port had to be adapted accordingly. The city government and the parliament adopted a comprehensive expansion program, which involved modernizing the petroleum port at Waltershof, constructing several new tank ship ports (Waltershof, Neuhof, Kattwyk, Schluisgrove), and deepening the Elbe to $11 \mathrm{~m}$. This would create 10 berths for large tankers, 17 berths for medium-sized tankers, and additional berths for smaller inland tankers and cleaning places. The cost of DEM 65.8 million would be offset by using the dredging material for landfilling in other areas of the port and amortize itself within a few years with additional revenue from the oil industry. This expansion program was completed in $1963 .{ }^{33}$

The dredging of access routes and the construction of larger berths were conventional measures to adapt the port's spatial layout to a changed economic environment. In response to European-wide debates about entirely new ways of importing oil—such as discharging

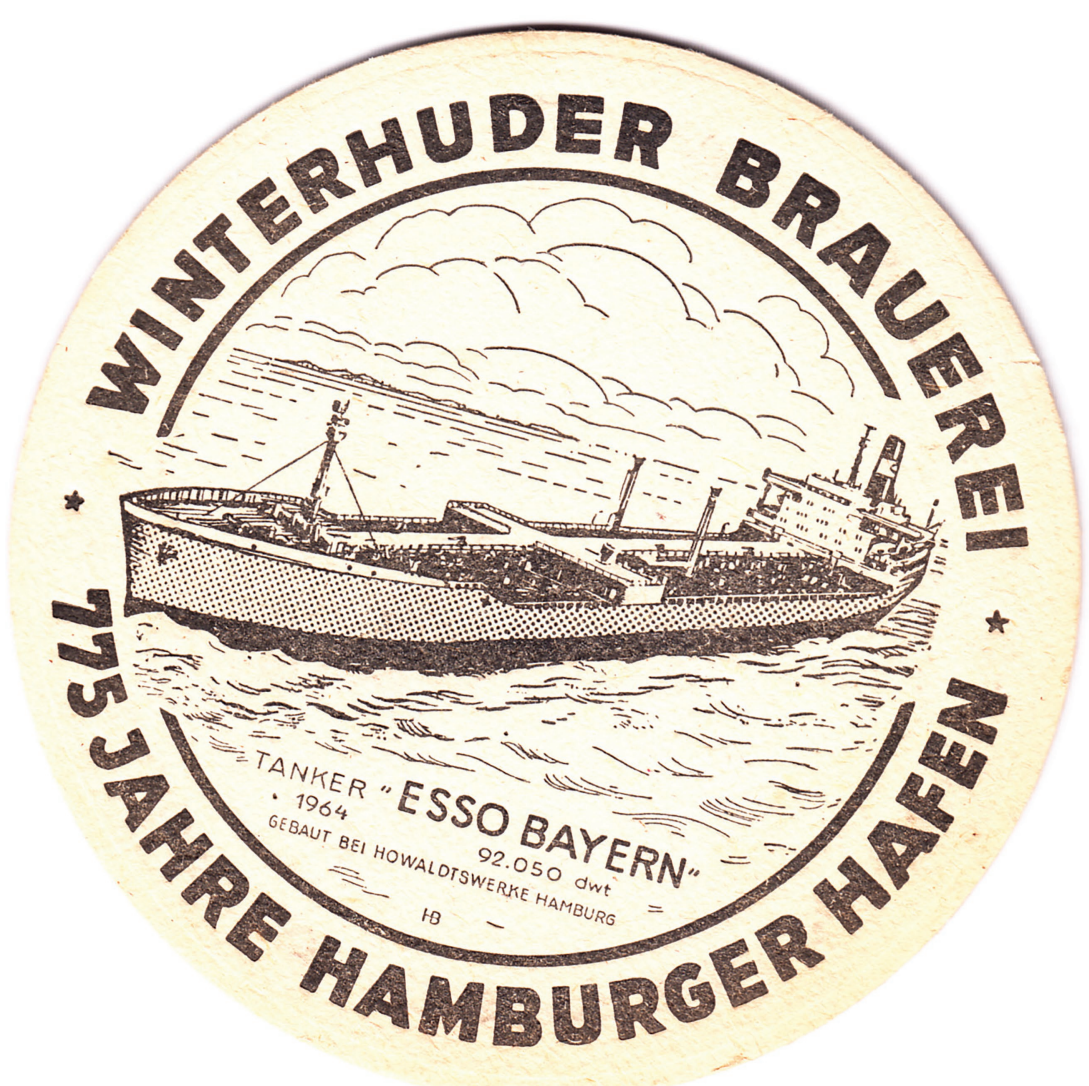

FIGURE 10.4 Beer mat of a local brewery celebrating the 775th port anniversary in 1964 with a drawing of the Esso Bayern. Source: Collection C. Strupp. 
tankers at sea at floating port facilities or specialized oil ports at geologically suitable sitesin November 1960, the city government revealed plans to build an offshore port for large bulk carriers at the island of Neuwerk, a Hamburg exclave at the Elbe estuary; but such an outward growth of the petroleumscape in the end never happened. Due to economic and technological changes in the 1960s and 1970s, and after years of fruitless planning and discussions, the Neuwerk plan was abandoned in 1979. ${ }^{34}$ In Hamburg, the industrial footprint within the spatial layer of the petroleumscape did not grow beyond the established port area and the port did not expand beyond city limits.

\section{Clouds over Hamburg: Spatial and Representational Dimensions of the Petroleumscape in the 1960s}

The Neuwerk plan and the restructuring of parts of the port to accommodate larger tank ships came at a time when the general conditions of the oil supply of the Federal Republic and the status of Hamburg as an "oil city" had already started to change. A few months before the memorandum of 1956 predicting the need to increase Hamburg's oil-handling capacity, the West German Federal Government decided to fund a specialized oil port in Wilhelmshaven on the coast of Lower Saxony. A pipeline to refineries near Cologne in the Rhineland went into operation at the end of 1958; as early as 1960, Wilhelmshaven replaced Hamburg as the leading oil port. ${ }^{35}$ In addition, in July 1960, a pipeline from Rotterdam to the Rhine-Ruhr area became operational, and later pipelines from Mediterranean ports started to serve Southern Germany. Before the construction of the pipelines, in 1957, 100 percent of West German crude oil imports had been discharged directly in the ports. This rate fell to 22 percent within a decade. ${ }^{36}$ In terms of production facilities, the landscape diversified. New refineries were built in western and southern Germany, close to main areas of consumption. They received their crude oil at competitive prices from Rotterdam via the pipelines and from German extraction sites. Even in 1957, the capacity of the eight refineries at the Rhine and Ruhr outnumbered that of the Hamburg plants. In 1960, the share of Northern German refineries in Hamburg (BP, Shell, Esso, Oelwerke Schindler), Bremen (Mobil Oil), and Heide (Texaco) amounted to 27.1 percent of the total capacity of the Federal Republic, but dropped to 14.9 percent within a decade. ${ }^{37}$

Hamburg's politicians argued that the pipelines were no competition since they transported oil to regions outside of Hamburg's trading area in Northern Germany. ${ }^{38}$ However, this trading area had shrunk and the increase in oil turnover at the port was flattening. Experts of the Hamburg Ministry for Economic Affairs admitted this as early as $1960 .{ }^{39} \mathrm{It}$ was also reflected in a debate on the status of the tank ship expansion program in parliament in 1960, but members reaffirmed that "in the context of the European Economic Community Hamburg has to make sure not to be pushed aside by the so-called Europoort position which certain ports claim for themselves." 40 This was aimed at Rotterdam, Europe's leading oil port, which expanded its port toward the North Sea and added almost 6,000 ha of space between 1952 and $1973 .^{41}$

In the second half of the 1960s, Hamburg had more than thirty berths for tank ships in three of its seven port groups (Waltershof, Kattwyk-Hohe Schaar, and Harburg), the largest of which were able to handle ships with a capacity of 60,000-70,000 tons. However, the Howaldtswerke in Kiel had already filled orders for ships of up to 171,000 tons and in Japan ships with more than 200,000 tons were under construction. In the Federal Republic of 
Germany, only Wilhelmshaven could keep pace with this trend; that port gradually expanded to accommodate ships with up to 250,000 tons by 1975.

In terms of sales volume, in the early 1960s the mineral oil industry in Hamburg remained at the forefront of the port industries. However, while the shipyards employed some 33,000 people, the oil industry provided only around 8,600 jobs (out of a total of 235,000 industrial workers in Hamburg). ${ }^{42}$ While the time of major enlargements of storage and processing capacities in the port in Hamburg was over-the newly designated port areas of the Port Development Act of 1961 were never used for the oil industry - and Esso, for example, now celebrated the opening of new refineries in Karlsruhe (1963) and Ingolstadt (1964), the oil cluster in the port continued to benefit from the unabated demand for oil and oil products. In 1968, Esso announced an investment of DEM 150 million to expand the capacity of its Harburg refinery from 3.6 to 5.5 million tons of crude oil annually. ${ }^{43}$ The small Oelwerke Julius Schindler built additional processing units for lube oil products at its refinery in Neuhof (1963-1967). ${ }^{44}$ A signal of confidence in the long-term future of oil in Hamburg followed in 1969, when Esso and Deutsche BP announced the founding of a company to study the construction of a pipeline from Wilhelmshaven to Hamburg. The pipeline, which in the end was not built until 1981, would have strengthened the position of the local refineries but would have meant for the port a yearly loss of several million tons of cargo. Ministry for Economic Affairs consoled itself with the added value the expansion of the capacities of the refineries would bring. ${ }^{45}$ In the early 1970s, crude oil imports in Hamburg had become local traffic that, in contrast to other goods, had no competition with other ports.

In the second half of the 1960s, the needs of the oil industry no longer dominated port planning in Hamburg, but planners focused on a broader range of services and goods. ${ }^{46}$ As in many other ports, the introduction of intermodal containers revolutionized general cargo handling. This fundamental change in maritime shipping posed new challenges to port authorities, port cities, and their strained budgets, but offered also new business opportunities. In terms of added value for the ports, oil compared unfavorably to other bulk and general cargo. The occupation of large areas of port property by the oil industry also came under critical review. From an economic point of view, it seemed to be more appropriate to concentrate on general cargo and to promote "modern" industries. Hamburg shifted its economic strategy in this direction with a comprehensive plan for promoting the "industrialization of the lower Elbe region." Profitable aluminum, steel, and chemical plants were to be attracted to Hamburg and the Elbe region and supplied with cheap energy via nuclear power stations. ${ }^{47}$

In the late 1960s, the industrial dimension of the spatial layer of the petroleumscape in the port of Hamburg stagnated but persisted - not the least because of the strong infrastructural path dependencies created by oil storage and production facilities. However, the administrative petroleumscape evolved and expanded into an entirely new area of the city, further away from the port and the prestigious inner city. The oil industry reaffirmed its commitment to Hamburg when four major companies relocated their headquarters to spacious modern office buildings in the "City Nord." Werner Hebebrand, Hamburg's director of urban development, had planned this cluster of large functional office buildings north of the city center on former garden land in the late 1950s, when congestion in the inner city increased and several companies in Hamburg demanded additional space for their administrations. Renowned contemporary architects designed the decidedly modern buildings. Esso moved into its new building in 1968, Deutsche BP in 1971, Deutsche Shell AG in 1974, and finally Texaco in 1977 (Figure 10.5). ${ }^{48}$ Groundbreaking ceremonies and the openings of the buildings always 
took place in the presence of high-ranking members of the local government. Private institutions such as the prestigious Overseas Club, in which almost all the CEOs and other senior staff were members, also provided opportunities for political networking. ${ }^{49}$

The spatial petroleumscape in Germany was adjusted in the 1960s with the rise of Wilhelmshaven and the Rhine region, the refineries in Bavaria and Baden-Württemberg, and the introduction of the pipelines as an alternative to shipping. Hamburg remained a prominent knot in this web because of the combination of storage and production sites in the port and administration headquarters in the city.

\section{Coping with Crises: Adjustments of the Petroleumscape in Hamburg Since the 1970s}

In the 1970s, the question of the energy supply of Western Europe increasingly changed from a technical to a policy issue and moved from national to supranational levels. ${ }^{50}$ At the beginning of the decade, Rotterdam had developed into the central hub of the petroleum sector in Europe. Wilhelmshaven, Hamburg, and Antwerp together accounted for only one-third of Rotterdam's oil turnover. ${ }^{51}$ Regardless of the flattening growth rates of crude oil in Hamburg in the 1960s, optimism still prevailed at the Elbe. In September 1971, the Department for Economic Affairs signed a contract with Dutch Paktank N.V. on the construction and operation of a large storage tank on the Hohe Schaar, which was supposed to bring an additional 2-3 million tons of crude oil to the port annually. In October 1972, Esso reopened its expanded facility in Harburg and other refineries expanded their capacities as well. ${ }^{52}$ Hamburg's refineries had a combined capacity of more than 13 million tons, but Deutsche BP, Esso, and Deutsche Shell all operated larger facilities at other locations. ${ }^{53}$

The first "oil crisis" of 1973 was, in political and psychological terms, a shock to contemporaries. It is regarded as a fundamental divide in the history of the second half of the twentieth century. ${ }^{54}$ In the port of Hamburg and the local oil industry, however, the crisis
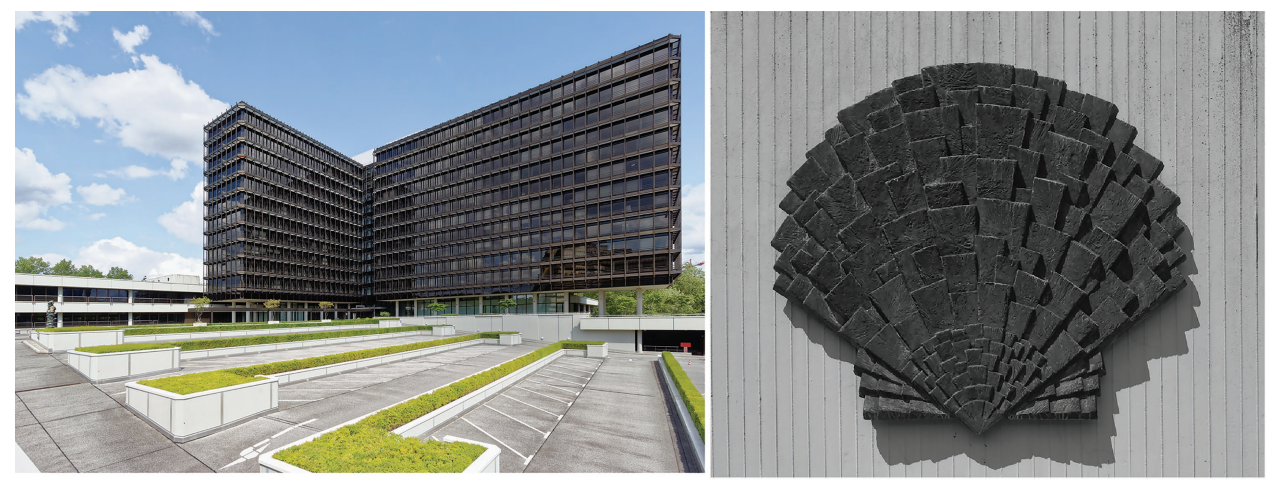

FIGURE 10.5 Office building of Deutsche Shell AG in the "City Nord," designed by the architect Meinhard von Gerkan; Ornament at the entrance of the building. Source: Wikimedia Commons, https://commons.wikimedia.org/wiki/File:Ex_shell_ überseering_35_06.jpg/https://commons.wikimedia.org/wiki/File:Ex_shell_ überseering_35_02.jpg, Author: Dirtsc, Date: July 18, 2015, CC BY-SA 4.0 (https://creativecommons.org/licenses/by-sa/4.0). 
did not leave deep traces. The total turnover in the port recovered within a year (see Table 10.2). The import of crude oil dropped slowly from 12.12 million tons in 1970 to 9.85 million tons in 1980. In addition, finished oil products of about 4-5 million tons annually were handled in the port in the 1970s. Nevertheless, in 1976 oil companies stopped all future expansion plans for their coastal sites. ${ }^{55}$

The second "oil crisis" of 1979-1980 with its massive price increases and a 25 percent reduction in consumption within four years drove the port of Hamburg and the local oil industry into a fundamental crisis. ${ }^{56}$ From 1982 to 1983, the port experienced a record drop in total turnover from 61.9 to 50.8 million tons. In the German oil industry, production capacities were cut in half within a few years, after capacity utilization had dropped to 57 percent in the early 1980s (see Tables 10.2 and 10.3). The crisis affected northern Germany in particular because the market there could be supplied cost-effectively with finished oil products from abroad because of its access to transport routes. In the port of Hamburg, the import of finished products grew from 5.3 million tons in 1980 to 7.7 million tons in 1990, but could not compensate for the loss of crude oil. ${ }^{57}$

While the first "oil crisis" had hardly affected the spatial layer of the petroleumscape in northern Germany, the second "oil crisis" changed it significantly. In Wilhelmshaven, Mobil Oil closed its refinery in March 1985. ${ }^{58}$ In Hamburg, Deutsche BP reduced the capacity of its own refinery and of the Oelwerke Julius Schindler by a total of 2.1 million tons in 1979 and 1981. In 1983, crude oil processing was completely abandoned and in 1985, the refinery closed. Esso first reduced its capacities in 1985 and completely stopped production on January 12, 1987. The refinery was sold to Holborn Europa Raffinerie GmbH, which reopened the plant in 1988 on a smaller scale and obtained crude oil via the new pipeline from Wilhelmshaven. Only Deutsche Shell AG benefited from the closings of its competitors and expanded its Hamburg location because a more favorable product structure-less

TABLE 10.3 Mineral Oil Consumption in the Federal Republic of Germany and Crude Oil Distillation Capacity in Northern Germany, 1950-2005

\begin{tabular}{llll}
\hline Year & $\begin{array}{l}\text { Mineral Oil Consumption } \\
\text { in the Federal Republic of } \\
\text { Germany, in Millions of } \\
\text { Tons }\end{array}$ & $\begin{array}{l}\text { Crude Oil Distillation } \\
\text { Capacity in Northern Germany } \\
\text { (Schleswig-Holstein, Bremen, } \\
\text { Hamburg), in 1,000 Tons }\end{array}$ & $\begin{array}{l}\text { Crude Oil Distillation Capacity } \\
\text { in Northern Germany, } \\
\text { Percentage of West German/ } \\
\text { German Total Capacity }\end{array}$ \\
\hline 1950 & 4.052 & 2.635 & 49.2 \\
1955 & 9.746 & 6.570 & 44.3 \\
1960 & 28.730 & 10.970 & 26.4 \\
1965 & 74.278 & 16.470 & 18.9 \\
1970 & 124.447 & 17.910 & 13.6 \\
1975 & 129.599 & 21.350 & 12.4 \\
1980 & 138.948 & 20.630 & 12.1 \\
1985 & 121.595 & 13.250 & 12.1 \\
1990 & 122.811 & 11.930 & 11.8 \\
1995 & 130.204 & 12.700 & 12.1 \\
2000 & 125.032 & 14.250 & 12.6 \\
2005 & 117.502 & 14.250 & 12.3 \\
\hline
\end{tabular}

Source: Mineralölwirtschaftsverband e.V., Jahresbericht Mineralöl-Zahlen 2005 (Hamburg: Mineralölwirtschaftsverband e.V., 2006), 27, 51. 
gasoline and heating oil, more petrochemical basic materials - made it possible to adapt to the changed market conditions. ${ }^{59}$

Port and port city officials had little influence on the location decisions of international corporations. Two of the three potential strategies to overcome the crisismodernization, partial withdrawal, or closure-would inevitably lead to a loss of turnover and possibly to abandoned land in the ports, which could not easily be reused. This was the case in Hamburg, for example, with the BP site at Finkenwerder. ${ }^{60}$ However, the industrial layer of the petroleumscape in the port of Hamburg remained strong and the oil industry is to this day a factor in the local economy. With the exception of the old petroleum port at Waltershof, almost all the oil sites-from the small area next to Kleiner Grasbrook at the Norderelbe, today occupied by Sasol Wax and Deutsche Shell, to the Harburg-Wilhelmsburg cluster, today occupied by H\&R Oelwerke Schindler, Vopak Dupeg storage tanks, Haltermann, Nynas specialty oils, Holborn, and others-are still in use. This confirms Carola Hein's observation of the "staying power" of refineries. ${ }^{61}$

In the 1990s and early 2000s, with some delay, the administrative layer of the petroleumscape also changed again. The major oil companies maintained their presence in Hamburg, but abandoned the spacious office buildings in the City Nord in favor of smaller headquarters throughout the city. The Mineralölwirtschaftsverband e.V. moved to Berlin in December 2008, as did the Uniti in 2009, but other lobby groups such as the Verband Schmierstoffindustrie e.V. stayed in Hamburg. In public life, oil remained visible in various ways: cultural aspects of the representational layer of the petroleumscape were manifest, for example, in the sponsorship of the major league soccer team Hamburger Sport-Verein by Deutsche BP (1979-1987) and the Hamburg-Marathon by Deutsche Shell (1991-1999) (Figure 10.6).

\section{Conclusion}

This chapter has provided an overview of dimensions of the petroleumscape in Germany's biggest seaport city Hamburg since the early 1860s. In the port, petroleum shaped much of the expansion process of the port area in the Kaiserreich and the interwar years. In the 1950s and 1960s, further port growth was limited by the political borders of the city-state and its upstream location. Port planners accommodated the spatial demands of the oil industry through the reallocation of port land and some adjacent areas. The introduction of pipelines and the oil crises of the 1970s ended new projects in Hamburg, but the oil industry maintained most of the established storage and production sites, underlining the path dependencies that large-scale industrial investments create.

The administrative dimension of the petroleumscape in Hamburg with its company headquarters and additional oil-related institutions and associations had originally formed a tight cluster in the inner city, not far from the port and close to the city hall and the headquarters of shipping companies, trading houses, and banks. In the late 1960s, this cluster disintegrated when more than two dozen companies, including the four major oil companies, moved their headquarters to the newly built City Nord. Since the 1990s, the administrative layer of the petroleumscape has changed again and further dispersed throughout the city.

For the port of Hamburg, the economic importance of oil grew in the interwar period and reached its peak in the late 1950s and early 1960s. Crude oil strengthened local traffic 


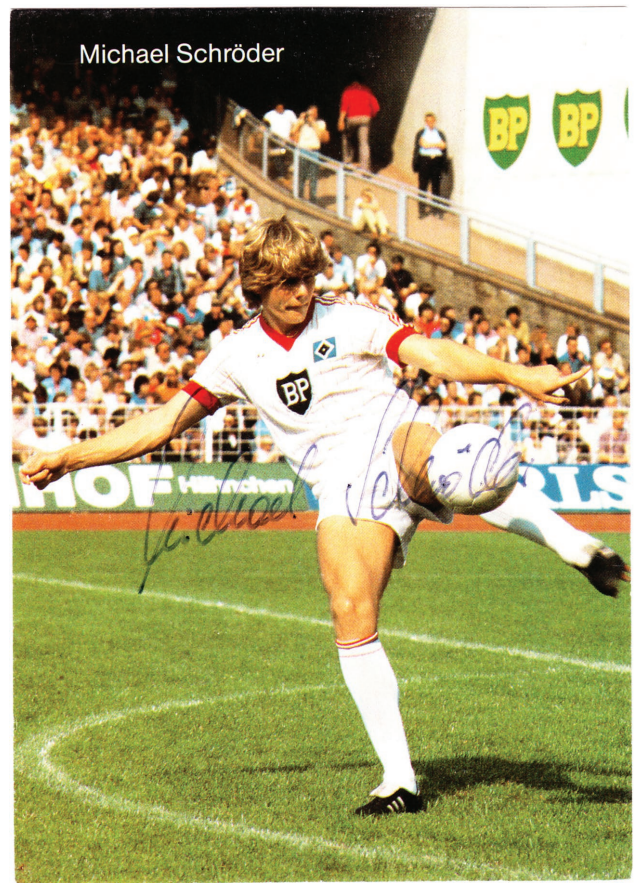

FIGURE 10.6 Autographed card of a Hamburg soccer player with the BP logo on his sports shirt and on the stadium wall, mid-1980s. Source: Collection C. Strupp.

and partially made up for the loss of cargo in Eastern Europe after the war. For the city, the oil industry has been a profitable branch of the industrial portfolio throughout the twentieth century. Representations of Hamburg as Germany's “oil city," however, had to compete with established perceptions of Hamburg as a city of trade whose image was shaped by colonial goods and later on by containers.

\section{Notes}

1 "Hafen Hamburg Jahrespressekonferenz 2017," https://www.hafen-hamburg.de/downloads/ media/dokumente/hhm-jpk-2017-16zu9.pdf.

2 Carola Hein, "Oil Spaces: The Global Petroleumscape in the Rotterdam/The Hague Area," Journal of Urban History 44, no. 5 (2018): 887-929.

3 Carola Hein, "Between Oil and Water: The Logistical Petroleumscape," in The Petropolis of Tomorrow, eds. Neeraj Bhatia and Mary Casper (New York: Actar, 2013), 436-47.

4 Arnold Kludas, Dieter Maass, and Susanne Sabisch, Hafen Hamburg: Die Geschichte des Hamburger Freihafens von den Anfängen bis zur Gegenwart (Hamburg: Kabel, 1988); Wolfgang Michalski, Hamburg: Erfolge und Erfahrungen in der globalisierten Welt (Hamburg: Murmann, 2010).

5 Ralf Lange, Hamburgs Welterbe: Speicherstadt und Kontorhausviertel (Hamburg: Junius, 2016).

6 Oliver Lieber, Hafen versus Stadt: Konfliktanalyse der Flächenkonkurrenz zwischen Hafenwirtschaft und Stadtentwicklung in Hamburg (Wiesbaden: Springer Fachmedien, 2018), 126.

7 Ernst Hieke, Wilhelm Anton Riedemann: Anfang und Aufstieg des deutschen Petroleumhandels in Geestemünde und Hamburg, 1860-1894 (Hamburg: Verlag Hanseatischer Merkur, 1963); Dieter Maass, Der Ausbau des Hamburger Hafens 1840 bis 1910 (Hamburg: Hansa, 1990), 78-81, 125-30, 192-93; Matthias Rademacher, Die Geschichte des Hafen- und Schiffahrtsrechts in Hamburg, vol. 4: 
Die Entwicklung des Hamburger Hafens und Hafenrechts von der Jahrhundertwende bis zur Gegenwart (Hamburg: Rademacher, 1999), 120-126; Rainer Karlsch and Raymond G. Stokes, "Faktor Öl”: Die Mineralölwirtschaft in Deutschland, 1859-1974 (Munich: C. H. Beck, 2003), 30-36, 56-62, 84-90.

8 Handels-Adreßbuch Hamburg: Ausgabe 1922 (Hamburg: Rößler \& Delbeck, 1922). See also Wilhelm Ehricht, "Hamburgs Mineraloel-Handel und -industrie: Seine Bedeutung für Deutschland" (PhD diss., University of Hamburg, 1925).

9 Carola Hein, "Hamburg's Port Cityscape: Large-scale Urban Transformation and the Exchange of Planning Ideas," in Port Cities: Dynamic Landscapes and Global Networks, ed. Carola Hein (London: Routledge, 2011), 184-91.

10 “Neuer Riesenbau an der Binnenalster," Hamburger Nachrichten, March 2, 1936.

11 “Der Neubau des DAP-Verwaltungsgebäudes," Hamburger Fremdenblatt, October 8, 1936.

12 Karlsch and Stokes, "Faktor Öl," 156-202; Klaus Weinhauer, "Handelskrise und Rüstungsboom: Die Wirtschaft," in Hamburg im "Dritten Reich,” ed. Forschungsstelle für Zeitgeschichte in Hamburg (Göttingen: Wallstein, 2005), 202, 215-18.

13 Robert Millward, Private and Public Enterprise in Europe: Energy, Telecommunications and Transport 1830-1990 (Cambridge: Cambridge University Press, 2005), 212.

14 Fünf Jahre Wiederaufbau: Tätigkeitsbericht der Esso AG 1945-1951, ed. Esso AG (Hamburg: Hanseatische Druckanstalt, 1951), 25. All translations from German source quotes by the author.

15 Arved Bolle, "Der Generalplan für den Ausbau des Hamburger Hafens von 1947," in Die Neugestaltung des Hamburger Hafens, ed. Verwaltung für Wirtschaft und Verkehr (Hamburg: Verwaltung für Wirtschaft und Verkehr, 1947), 20-27.

16 "215 Tanks in einer Mondlandschaft," Hamburger Abendblatt, November 5, 1949.

17 Behörde für Wirtschaft und Verkehr, Amt Strom- und Hafenbau, Grundlagen für den künftigen Ausbau des Hafens Hamburg (Hamburg: Behörde für Wirtschaft und Verkehr, 1960), 7a, 8.

18 “Ölstadt Hamburg," Die Zeit, July 21, 1949; Sven von Müller, “Ölstadt Hamburg. Drei Säulen: Selbstvertrauen, Wille und Können," in Neues Hamburg, vol. X: Die Wiederaufrichtung Hamburgs 1945-1955, ed. Erich Lüth (Hamburg: Hammerich und Lesser, 1955), 87-88; "Hamburg, das große Ölzentrum der Bundesrepublik," Hamburger Abendblatt, May 7, 1954, addendum.

19 “Türme des 20. Jahrhunderts," Hamburger Abendblatt, April 29, 1954.

20 Müller, "Ölstadt," 88; Klaus-Jürgen Juhnke, "Die Bedeutung der Mineralölindustrie des Hamburger Hafens für Kosten und Erträge des Hamburger Staates" (Thesis, University of Hamburg, 1962), 41-42.

21 Hansgeorg Günter, Mineralöl-Handbuch (Hamburg: Christen, 1950); Curt Weber, “Mineralölindustrie: Rohöle aus Venezuela und dem Mittleren Osten," in Hamburg als Industrieplatz, eds. Handelskammer Hamburg and Behörde für Wirtschaft und Verkehr (Hamburg: Hammerich und Lesser, 1952), 68-69; "Hamburg, das große Ölzentrum der Bundesrepublik," Hamburger Abendblatt, May 7, 1954, addendum; "Hamburg: Deutschlands Ölhafen Numer eins," Hamburger Abendblatt, May 7, 1957, addendum.

22 Notes and Correspondence of the Ministry for Financial Affairs, State Archive Hamburg 311-3 I: 196: Erweiterung der Ölindustrie im Hamburger Hafen, 1954-1955; 311-3 I, Abl. 1981: 41018/69: Erweiterung der Ölindustrie im Hamburger Hafen, Vol. 1-2, 1955-1960 (1962, 1964).

23 Michael B. Miller, Europe and the Maritime World: A Twentieth-Century History (Cambridge: Cambridge University Press, 2012), 311.

24 Notes and Correspondence of the Ministry for Economic Affairs, State Archive Hamburg 371-16 II: 4001: Firmen der Mineralölwirtschaft (Beispielakte), Deutsche Shell AG, 1951-1961.

25 Stenographische Berichte über die Sitzungen der Bürgerschaft zu Hamburg im Jahre 1956 (Hamburg: Auerdruck, 1956), 760.

26 Rademacher, Geschichte, 418-19.

27 Miller, Europe, 307-308.

28 Behörde für Wirtschaft und Verkehr, Amt Strom- und Hafenbau, Grundlagen für den künftigen Ausbau des Hafens Hamburg (Hamburg: Behörde für Wirtschaft und Verkehr, 1960), 7-8; Behörde für Wirtschaft und Verkehr, Hafen Hamburg 1945-1965: Zwanzig Jahre Aufbau und Entwicklung (Hamburg: Behörde für Wirtschaft und Verkehr, 1965), 13-14.

29 E. Förster, "Warum so große Tanker?," Hamburger Abendblatt, December 9, 1953.

30 "Ein Festtag für den Hamburger Hafen," Hamburger Abendblatt, February 20, 1963. 
31 Hans-Henning Kroll, "Sie sind zu groß für Europas Küsten: Tanker-Giganten finden keine Häfen mehr," Hamburger Abendblatt, September 27, 1966; Lu Seegers and Christoph Strupp, "Hafenund Handelsstadt oder Stadt der Industrie? Wirtschaftspolitik und Deutung des Strukturwandels in Hamburg," in Wirtschaftsräume und Lebenschancen: Wahrnehmung und Steuerung von sozialökonomischem Wandel in Deutschland 1945-2000, eds. Stefan Grüner and Sabine Mecking (Berlin: De Gruyter Oldenbourg, 2017), 205-22.

32 Behörde für Wirtschaft und Verkehr, Zur Frage der Hamburger Tankschiffhäfen (Hamburg: Behörde für Wirtschaft und Verkehr, 1956); Hans Laucht, "Planung und Bau neuer Tankschiffhäfen in Hamburg," Handbuch für Hafenbau 3 (1957): 233-39.

33 Juhnke, "Bedeutung," 81-99, 124-52.

34 Rademacher, Geschichte, 413.

35 Jörn Eiben, Industriestädte und ihre Krisen: Wilhelmshaven und Wolfsburg in den 1970er und 1980er Jahren (Göttingen: Wallstein Verlag, 2019), 50-51; Marten Boon, Multinational Business and Transnational Regions: A Transnational Business History of Energy Transition in the Rhine Region, 1945-1973 (New York: Routledge, 2018) Boon, Multinational Business, 108-15; Juhnke, "Bedeutung," 154-56.

36 Boon, Multinational Business, part II; Michael Poppe, Integration von Infrastrukturen im historischen Vergleich, vol. 5: Öl- und Treibstoffpipelines (Baden-Baden: Nomos, 2015); Miriam Bader-Gassner, "Pipelineboom:" Internationale Ölkonzerne im westdeutschen Wirtschaftswunder (Baden-Baden: Nomos, 2014).

37 Boon, Multinational Business, 64, 85-92; Wolfgang Viernow, Mineralölpipelines: Ihre Funktion und ihre Stellung im Verkehrssystem der Bundesrepublik (Cologne: DVWG, 1971), addendum 3.

38 Hubert van Drimmelen, "Mineralölzentrum Hamburg wird sich behaupten," Hamburger Journal 8, no. 5 (1960): 43-44; Klaus Kramer, "Für Hamburg keine Konkurrenz," Hamburger Abendblatt, August 17, 1963.

39 Uwe Christiansen, "Hamburg im Seehafen-Wettbewerb," Wirtschafts-Correspondent 14, no. 9 (1960): 14.

40 Stenographische Berichte über die Sitzungen der Bürgerschaft zu Hamburg im Jahre 1960 (Hamburg: Auerdruck, 1960), 481.

41 Hein, “Oil Spaces," 908, 912, 917-20; Boon, Multinational Business, 154-58; Ferry de Goey, Ruimte voor industrie: Rotterdam en de vestiging van industrie in de haven, 1945-1975 (Delft: Eburon, 1990).

42 Juhnke, "Bedeutung," 37-42.

43100 Jahre Dapolin: Dapolin-Benzin, Standard, Esso 1890-1990, ed. Esso AG (Hamburg: Esso AG, 2009), entry for 1968.

44 Theo Müller and Annette Schlapkohl, 100 Jahre Schindler: Chronik einer Hamburger Firma (Husum: Husum Druck- und Verlagsgesellschaft, 2008), 46-48.

45 Hans Spilker, "Keine Prestige-Investitionen! Zum Bericht der Tiefwasserhäfen-Kommission," Wirtschaftsdienst 52 (1972): 204; Wilhelm Voss, "Hamburg als Massenguthafen," Hansa 110 (1973): 832-833.

46 M. S. Husain, "Influences on Development Policy in the Port of Hamburg," in Cityport Industrialization and Regional Development: Spatial Analysis and Planning Strategies, eds. Brian S. Hoyle and David A. Pinder (Oxford: Pergamon Press, 1981), 232, 239.

47 Husain, "Influences," 232; Helmuth Kern, Ein Modell für die wirtschaftliche Entwicklung der Region Unterelbe (Hamburg: Behörde für Wirtschaft und Verkehr, 1970).

48 Sylvia Soggia, City Nord: Europas Modellstadt der Moderne (Munich: Dölling und Galitz, 2009); Carola Hein, "City Nord - eine Geschäftsstadt im Grünen," in Das ungebaute Hamburg: Visionen einer anderen Stadt in architektonischen Entwürfen der letzten hundertfünfzig Jahre, ed. Ulrich Höhns (Hamburg: Junius, 1991), 200-9.

49 Übersee-Club e.V., Mitgliederverzeichnis, Mai 1963 (Hamburg: Übersee-Club e.V., 1963).

50 Martin Czakainski, "Energiepolitik in der Bundesrepublik Deutschland 1960 bis 1980 im Kontext der außenwirtschaftlichen und außenpolitischen Verflechtungen," in Energie - Politik - Geschichte: Nationale und internationale Energiepolitik seit 1945, eds. Jens Hohensee and Michael Salewski (Stuttgart: F. Steiner, 1993), 17-34; Rüdiger Graf, Öl und Souveränität: Petroknowledge und Energiepolitik in den USA und Westeuropa in den 1970er Jahren (Berlin: De Gruyter Oldenbourg, 2014).

51 Johannes Marx, "Der Hamburger Hafen als Energieumschlagplatz," Hamburg in Zahlen, no. 4 (1974): 98-100. 
52 “85 Millionen für den Hafen," Hamburger Abendblatt, September 3, 1971; Klaus Repenning, "Die Zukunft der Petrochemie," in Hamburg auf dem Weg in das Jahr 2000: Prognosen, ed. Ernst Schmacke (Düsseldorf: Droste, 1970), 224-35.

53 Erich Schieweck, "Wirtschaftliche und politische Aspekte des Erdöls in den siebziger Jahren," Glückauf 106 (1970), 807.

54 Jens Hohensee, Der erste Ölpreisschock 1973/74: Die politischen und gesellschaftlichen Auswirkungen der arabischen Erdölpolitik auf die Bundesrepublik Deutschland und Westeuropa (Stuttgart: F. Steiner, 1996); Stefan Göbel, Die Ölpreiskrisen der 1970er Jahre: Auswirkungen auf die Wirtschaft von Industriestaaten am Beispiel der Bundesrepublik Deutschland, der Vereinigten Staaten, Japans, Großbritanniens und Frankreichs (Berlin: Logos, 2013).

55 K.-D. Fischer, "Stagnation der westeuropäischen Raffineriekapazität," Annuaire européen du pétrole (1976): 44-50.

56 Hans Michaelis, "Die Energiewirtschaft der Bundesrepublik Deutschland 1970 bis 1990," in Energie - Politik - Geschichte: Nationale und internationale Energiepolitik seit 1945, eds. Jens Hohensee and Michael Salewski (Stuttgart: F. Steiner, 1993), 52-53; Hohensee, Ölpreisschock, 78.

57 Bernhard Hnat, Strukturwandel in der mineralölverarbeitenden Industrie der Bundesrepublik Deutschland: Untersuchung über das Anpassungsverhältnis der Mineralölgesellschaften als Folge der Ölkrisen (Göttingen: Vandenhoeck \& Ruprecht, 1992), 61; Susanna Degrassi, “The Seaport Network Hamburg” (Dissertation, University of Hamburg, 2001), 281-82.

58 Eiben, Industriestädte, 225-28.

59 Rademacher, Geschichte, 470-72; Hnat, Strukturwandel, 109, 115.

60 Carola Hein, “'Old Refineries Rarely Die': Port City Refineries as Key Nodes in the Global Petroleumscape," Canadian Journal of History 53 (2018): 476-79; David A. Pinder and Sohail Husain, "Deindustrialisation and Forgotten Fallow: Lessons from Western European Oil Refining," in Revitalising the Waterfront: International Dimensions of Dockland Redevelopment, eds. Brian S. Hoyle, David A. Pinder, and M. S. Husain (London: Belhaven, 1988), 232-46.

61 Hein, "'Old Refineries'," 450. 